\title{
Microbial Cellulases: A Review on Strain Development, Purification, Characterization and their Industrial Applications
}

\author{
Sher $\mathbf{H}^{1,2}$, Zeb N1,3, Zeb S ${ }^{4}$, Ali $\mathbf{A}^{4}$, Aleem B', \\ Iftikhar $\mathrm{F}^{1}$, Rahman $\mathrm{SU}^{1}$ and Rashid $\mathrm{MH}^{1,2 *}$ \\ ${ }^{1}$ National Institute for Biotechnology and Genetic \\ Engineering (NIBGE), Faisalabad, Pakistan \\ ${ }^{2}$ Pakistan Institute of Engineering and Applied Sciences \\ (PIEAS), Islamabad, Pakistan \\ ${ }^{3}$ Department of Biotechnology and Microbiology, Women \\ University Mardan, KP, Pakistan \\ ${ }^{4}$ Department of Microbiology, Abdul Wali Khan \\ University Mardan, KP, Pakistan \\ "First two authors contributed equally \\ *Corresponding author: Muhammad Hamid Rashid, \\ Industrial Biotechnology Division, National Institute \\ for Biotechnology and Genetic Engineering (NIBGE), \\ Faisalabad, Pakistan
}

Received: May 17, 2021; Accepted: July 05, 2021; Published: July 12, 2021

\begin{abstract}
In this advance era, the enzymes are considered as a core kernel of white biotechnology and their demand is increasing day by day. According to report published in Research and Markets (ID: 5009185), the estimated global market for industrial enzymes were USD 10.0 billion in 2019, which is continuously increasing as it is expected to reach about USD 14.7 billion by 2022. Among all enzymes, cellulases are the major group of enzymes act synergistically in breakdown of cellulose, that facilitates its conversion to various value-added products and also offer several other important applications at industrial scale. The hyper production of cellulases are required to overcome their demand of global market. Cellulases production can be enhanced by strain improvement as well as using advance fermentation technology. In this review a detail studies of strategies to enhance production of cellulases and improve their physiochemical properties for industrial application have been described.
\end{abstract}

Keywords: Enzyme; Cellulase; Aspergillus; Immobilization; Fermentation; Strain improvement

\section{Abbreviations}

Mpa Pressure: Mega Pascal Pressure Unit; A. oryzae: Aspergillus oryzae; A. sojae: Aspergillus sojae; $\mathrm{CaCl}_{2}$ : Calcium Chloride; $\mathrm{NaCl}$ : Sodium Chloride; UV: Ultraviolet Radiations; SmF: Submerged Fermentation; CMC: Carboxymethyl Cellulose

\section{Introduction}

Enzymes are the proteinaceous macromolecules and biological catalysts that are produced by all living organisms and involved in vital processes of life. They are also considered as the most promising alternative to chemical catalysts as they are highly specific and can carry out the catalysis at very minimum and milder reaction conditions [13]. Enzymes are employed in various processes in industries as they are non-toxic, biodegradable and can produce higher concentration of better-quality products by utilizing small number of raw materials. Enzymes are sustainable at both in vivo and in vitro conditions [4]. Various living systems are used for the extraction of industrially important enzymes including; animals (Pepsin, Trypsin), plants (Papain, Bromelain) and microorganisms ( $a$-amylase, Glucoamylase, Cellulase) while bulk amount of enzymes can be obtained from microorganisms [5]. The demand for enzymes is increasing day by day and according to report published in Research and Markets (ID: 5009185), the estimated global market for industrial enzymes were USD 10.0 billion in 2019, which is continuously increasing so it is expected to reach about USD 14.7 billion by 2022. In this advance era, the enzymes are considered as a core kernel of biotechnology as they are the main agent to run important industrial biotechnological processes. In order to meet the increasing demands, enzymes are produced from microorganisms because they are the primary source of enzymes, having short life span, easy to culture and also desired genetic variations to enhance production of enzymes can be carried out easily comparative to plants and animals.

The enzymes produced by microorganisms are comparatively more stable as they can work in various temperature and $\mathrm{pH}$, therefore the microbial enzymes can be withstanding in industrial bioprocesses. The microorganisms can be also genetically modified or mutated to enhance the production of enzymes as well as to improve the enzymatic activity and stability [6]. The best renewable energy sources for microorganisms are lignocellulosic materials and this is also the major structural components of plants. It is composed of a complex mixture of carbohydrate polymers such as; cellulose, hemicellulose, lignin and some other components termed as extractives [7-9]. These all components of lignocellulosic biomass are interconnected with each other in different percentage and form a hetero-matrix. Mostly the composition of the main polymers of legionellosis biomass is; Cellulose (30-60\%), Hemi cellulosic (20-40 $\%)$, Lignin (10-25 \%) [10]. The plant genetics, environmental factors and the sources of biomass greatly influence the composition of polymers in lignocellulose materials [11]. The cellulose of biomass or plant cellulosic parts can be converted into sugars for further processing by cellulases enzyme followed by pre-treatments.

In recent few decades, the soluble sugar and other products obtained from the conversion of cellulosic materials was further used as precursor for the production of fuels, ethanol or other important biochemical products [12]. For this purpose, enzymes are playing an important role in the hydrolysis of cellulosic biomass and conversion to valuable products. Among all enzymes, cellulases are the major enzyme involved in breakdown of cellulose. Therefore, the cellulases produced through advanced biotechnological processes is further used for the depolymerisation of cellulose and also offers several 


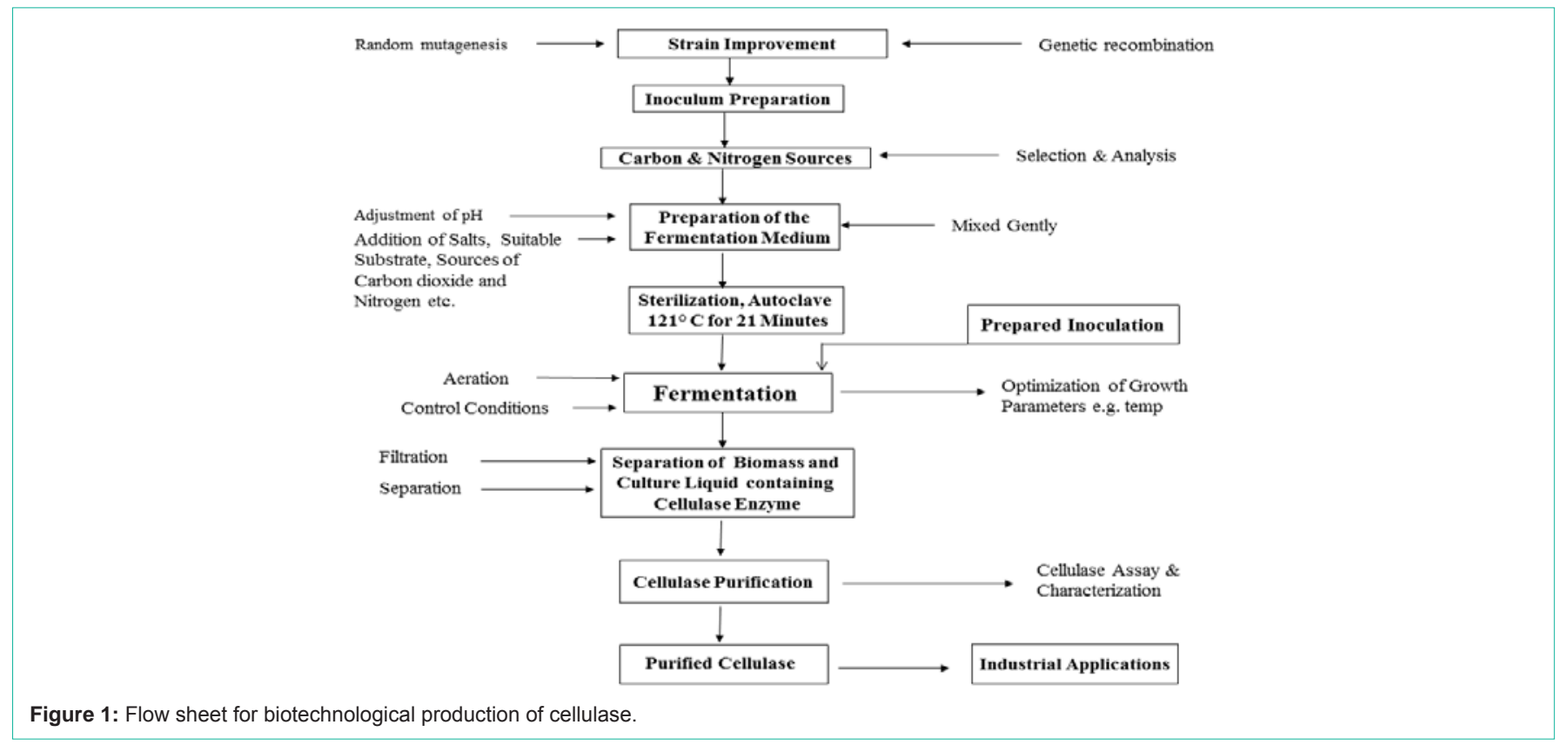

Figure 1: Flow sheet for biotechnological production of cellulase.

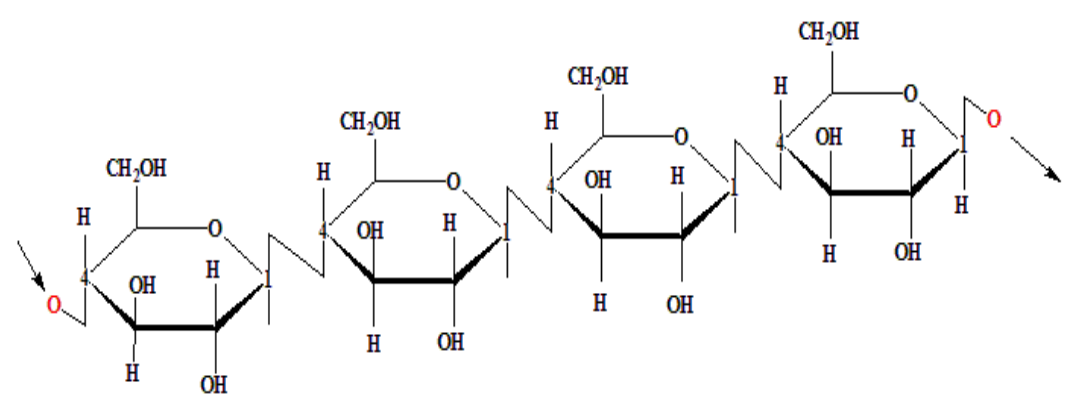

Figure 2: Diagram showing the $\beta-1,4$ linkages of glucose units in cellulose.

other important applications at industrial scale [13,14]. Though, few reviews are available on cellulase enzyme especially focusing on their biotechnological production and strategies to improve their productions and properties. However, in this review we have reported the methods of strain improvements for optimization of cellulases enzyme production through advanced fermentation technology and their industrials applications (Figure 1).

\section{Lignocellulosic Biomass}

Lignocellulose materials are the major structural components of plants and the best renewable energy sources for microorganisms. Lignocellulose biomass is composed by the polymerization of carbohydrate moieties such as; cellulose, hemicellulose, lignin and some other components, called as extractives and these moieties are the major constituents of plant cell wall [7-9]. The main component of lignocellulose materials is cellulose, which is the large homologous polymeric chain of $\mathrm{D}$-Glucose residues connected through $\beta-1$, 4 glycosidic bonds with the repeating small subunits, cellobiose (Figure 2) [12]. Cellulose is consider the most copious and bountiful renewable sources for producing valuable products for energy sources [6], this property of cellulose make it more important to use it for the production of value-added fuels by thermochemical or biochemical processes. This has been used for the production of biofuel especially for methane and bioethanol [15]. Beside this, the cellulose has also wide range of application and use in different industries such as food and beverage, animal feeds, detergent, agriculture, textile, pulp and paper industry. It has attracted the interest of industrial scientists, so these can be utilized for the production of enzymes such as cellulase, xylanase, $\alpha$-amylase at both lab and industrial scale [4]. It has also attracted the interest of scientists as they are taking advantage of using this low cost energy source (cellulose) for the production of biological products, that would add into the economy and energy security of the country [16].

Cellulose usually occurs as fibres, densely packed with hydrogen bond and insoluble in water so it is very resistant to hydrolysis without the chemicals and mechanical degradation. Hence cellulose or other polysaccharide compounds can be converted into simple sugar or glucose units by the activity of cellulase enzymes [17]. It is also a very stable part of plant cell wall matrix and biomass, that's why plants take great benefit of it as it plays an important role to maintain the cell wall stability and integrity [18]. The structure of cellulose determines the hydrolysis pathway and compactness in cellulosic structure makes it prone to the degradation. This compact and crystalline structure of cellulose is due to inter and intra molecular hydrogen bonding. This super crystalline structure of cellulose makes 


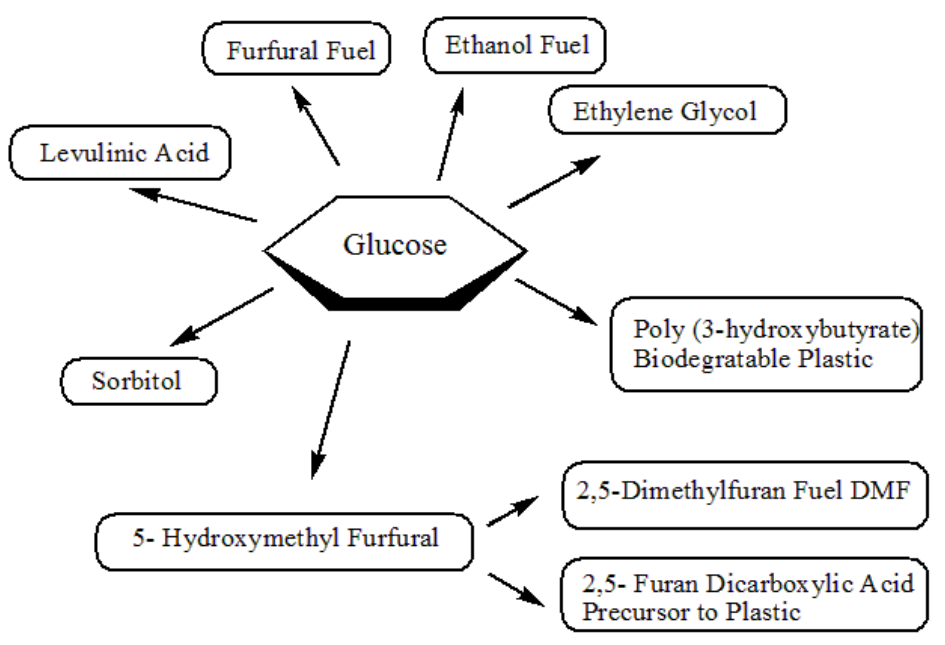

Figure 3: Fuels \& chemicals derived from glucose

it resistance to hydrolysis even at very extreme reaction conditions, therefore, it must be pre-treated to convert the cellulosic biomass or plant cellulosic parts into simple sugars. Therefore, before processing, it must be heated at $320^{\circ} \mathrm{C}$ at $25 \mathrm{MPa}$ pressure [6]. The procedure to convert the lingo-cellulosic biomass into valuable products is facilitated with the "Biochemical conversion process", which reduce the size of biomass by clipping. The biochemical conversion process is followed by the "Thermochemical pre-treatment step", which make the plant cell wall more flexible and amenable for the biocatalysts attack. Then cellulase can depolymerize the cellulose into sugar very easily, and furthermore the simpler sugars can yield valuable chemicals and fuels (Figure 3) [19-21].

\section{Factors Affecting the Hydrolysis Rate of Cellulose}

The hydrolysis of cellulose is the complex and sensitive process that requires the pre-treatment and action of one enzyme in a group form. The complex, compact and rigid structure of cellulose, make it strong enough, therefore, cannot cleaved easily by enzymatic action. But cellulose is the most abundant and biologically renewable resource for the production of many important products and fuel. So it is key interest of industries to hydrolyze the cellulose into glucose or simple sugars which is the further fermented to ethanol and many other valuable products. The hydrolysis of cellulose into individual units, that is, simple sugar or glucose or easily hydrolysable shorter chains depends on some factors including; crystallinity, degree of polymerization, particle size and pore volume and availability of surface area.

\section{Crystallinity}

Crystallinity is one of the major factors which affect the procedure of cellulose hydrolysis by enzymatic process. As we know that cellulose has highly crystalline chains and tightly packed nature that make cellulose resistance to hydrolyze by enzymatic activity. Therefore, the crystallinity of cellulose is inversely proportional to the enzymatic action. The process of hydrolysis will be slow, if the cellulose has more crystalline regions.

\section{Degree of polymerization}

The longer chain length of cellulose is also recalcitrant to hydrolysis. Therefore, cellulose with smaller chains will be hydrolyzed easily and vice versa.

\section{Particle size and pore volume}

The size, shape and pore volume of cellulose also has great influence on the hydrolysis of cellulose.

\section{Availability of surface area}

Mostly cellulose or chains of cellulose are buried inside the microfibers which reduce the rate of hydrolysis due to limited access of enzyme to the glycoside bonds [22,23].

\section{Cellulases Enzyme and Modes of Action}

The cellulases are the group of enzymes that hydrolyse the $\beta-1,4$ glycosides bond between $\beta$-D glucose units in cellulose. This group of enzymes, cellulases, are further classified into various types on the basis of their mechanisms of bond cleavage in cellulose resulting in the yield of different intermediate and end products. Moreover, the subtypes of cellulase also differ in amino acid sequence, folding and 3-D structure. The cellulase enzyme includes three major types; 1) Endoglucanase, 2) Exoglucanase or cellubiohydrolases, 3) $\beta$-Glactosidase. These enzymes are Glycoside Hydrolase (GH) which act synergistically on cellulose to breakdown into simple sugar for their application in industry e.g., textile, food, feed, pulp and paper industry [24-27]. The breaking down of cellulose molecules into simple sugars, cellobiose and other oligo-saccharides as a primary product starts with the carboxymethyl cellulase or endoglucanase, which reacts on chain of cellulose and randomly release a small fibre with non-reducing or reducing end. Afterwards, exoglucanase or cellubiohydrolases reacts on free ends of small fibres to release the cellobiose, and finally the $\beta$-glucosidase help by cleaving the cellobiose to the end product glucose (Figure 4) [28].

Cellulases are the world's third largest group of enzymes and have been considered as one of the most important targets for both academic and industrial research for more than 30 years. The structure of fungal cellulases are comparatively simpler than 


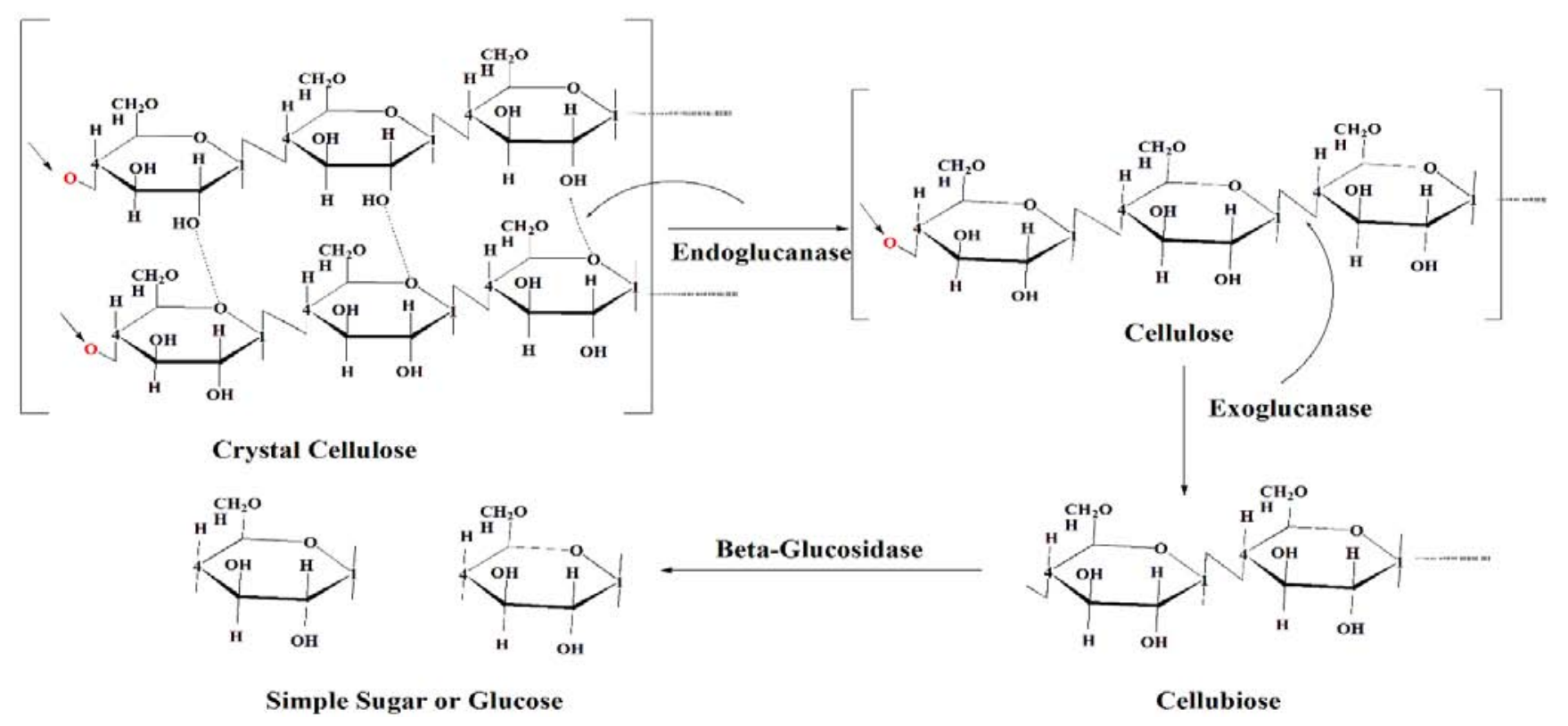

Figure 4: The hydrolysis mechanism of cellulose by cellulase.

Table 1: Cellulase Producing Microorganisms.

\begin{tabular}{|c|c|c|c|c|}
\hline \multirow{8}{*}{ Fungi } & Microbes & Ref & Microbes & Ref \\
\hline & Aspergillus niger & {$[136]$} & Trichoderma Longibrachiatum & [137] \\
\hline & Trichoderma Harzianum & [137] & Rhizopus sp. & [138] \\
\hline & Aspergillus ustus & [139] & Aspergillus terreus & [140] \\
\hline & Penicillium decumbens & [141] & Penicillium funiculosum & [142] \\
\hline & Trichoderma reesei & [143] & Aspergillus Fumigatus & [144] \\
\hline & Aspergillus unguis & [145] & Aspergillus tubingenesi & [146] \\
\hline & Aspergillus heteromorphu & [147] & Fomitopsis sp & [148] \\
\hline \multirow{5}{*}{ Bacteria } & Streptomyces Sp. G12 & [149] & B. subtilis & [150] \\
\hline & Anoxybacillus flavithermus & [150] & Bacillus stratosphericus & [151] \\
\hline & Vibrio parahaemolyticus & [152] & Bacillus pumilus EB3 & [153] \\
\hline & Bacillus mojavensis & [154] & Bacillus Amyloliquefaciens & [155] \\
\hline & Branhamella sp. & {$[156]$} & Microbulbifer hydrolyticus & [157] \\
\hline
\end{tabular}

that of bacteria known as cellulosome as it contains cellulosomecohesin containing enzymes for scaffolding and dockerin while fungal cellulases contains two domains; catalytic domain or catalytic modules and cellulose binding domain composed of 35 amino-acids and both domains are linked by short poly-linker which are rich in threonine and serine residues [29]. On the basis of three dimensional structure and amino-acid sequences, the catalytic domain is classified into different Glycoside Hydrolase (GH) families and a proton donor and nucleophile residues are present at the catalytic site that are involved in the catalysis of cellulose through acid-base mechanism [10]. Glycoside Hydrolase (GH) families 5-9, 12, 44, 45, 48, 51 and 74 are specific for endoglucanase [30]. In a study it was reported that the catalytic domain also known as "Concanavalin-like domain", is structurally same in both bacterial and fungal cellulases, binds through a short sequence to Cellulose Binding Domain (CBD) or cellulose binding module (CBM). The CBD is mostly found in bacterial enzymes and it also contains cellulosome, having both types of cellulases, that is; 1) Cellulases bind with CBD, 2) Cellulase without CBD [4]. The bacteria, fungi, protozoan, plants, and animal are the producers of cellulase (Table 1) [31,32].

\section{Strain Development}

Cellulases production can be enhanced by strain improvement through genetically modifying the microbial strains via advanced techniques, which has gained much importance [3]. Commercial production of cellulases is enhanced by genetic modifications and random mutagenesis of the parental strains [33]. Moreover, the molecular cloning of cellulases genes or increasing copy number also have great impact on degradation of cellulosic material and production of high quality value-added products [10].

Strain improvement is a promising approach for enhancing the production of cellulases [34]. The wild type or normal strains may possess some specific characteristics and found potential applications 
Table 2: Strain improvement through mutagenic treatments for enhancing cellulase production.

\begin{tabular}{|c|c|c|c|c|}
\hline \multicolumn{2}{|r|}{ Microbial Strain } & \multirow{2}{*}{ 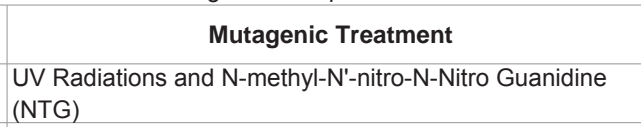 } & \multirow{2}{*}{\begin{tabular}{|l|} 
Effect on Cellulase Production (Folds, \\
Percentage)
\end{tabular}} & \multirow{2}{*}{\begin{tabular}{|l|} 
Ref \\
{$[158]$}
\end{tabular}} \\
\hline & Trichoderma viride TL-124 & & & \\
\hline & Penicillium janthinellum EU1 & UV Radiations and Ethyl-Methyl Sulphonate & 2 folds & [159] \\
\hline & Aspergillus sp. SUI4-M15 & Co60 y-rays, UV Radiations and NTG & 2.2 folds & [160] \\
\hline & Trichoderma reesei SCB18 & $\begin{array}{l}\text { Genetic Engineering (Deletion of cre } 1 \text { gene and cloning of } \\
\text { bglA from A. niger) }\end{array}$ & $29.80 \%$ & [161] \\
\hline Fungal & Trichoderma reesei- $\triangle \mathrm{P} 70$ & $\begin{array}{l}\text { Deletion of Protease genes (tre81070, tre } 120998 \text { and tre } \\
\text { 123234) }\end{array}$ & 6 folds & [163] \\
\hline \multirow[t]{4}{*}{ Strains } & Penicillium decumbens Mutant JU-A10-T & Genetic Engineering (Deletion of creA and amyR genes) & 9 folds & [164] \\
\hline & Trichoderma citrinoviride & Ethyl-Methyl Sulphonate and Ethidium Bromide & 2.10 folds & [165] \\
\hline & $\begin{array}{l}\text { Trichoderma reesei Mutants (TA-32, TB- } \\
87, \text { TE-6) }\end{array}$ & Agrobacterium mediated T-DNA Insertional Mutagenesis & $38 \%, 51 \% \& 31 \%$ respectively & [166] \\
\hline & Cellulomonas sp. TSU-03 (M23) & UV Radiations and N-methyl-N'-nitro-N-nitro guanidine & 1.30 folds & [167] \\
\hline \multirow[t]{5}{*}{ Strains } & Acidothermus cellulolyticus & Designed Mutation at active site & $40 \%$ & [169] \\
\hline & $\begin{array}{l}\text { Streptomyces griseoaurantiacus }\left(\mathrm{SG}_{\mathrm{Uv} 30}\right. \\
\left.\text { and } \mathrm{SG}_{\mathrm{Uv} 5}\right)\end{array}$ & UV Mutagenesis & $57.40 \%$ & [170] \\
\hline & Bacillus sp. Hcb-21 & $\begin{array}{l}\text { Chemical Mutagenesis (EMS, MMS, ENU, MMU \& } \\
\text { 5-bromouracil) }\end{array}$ & 10 folds & [171] \\
\hline & Bacillus N3 & Physical and Chemical (Nitrous acid) Mutagenesis & 1.7 folds & [172] \\
\hline & Acremonium cellulolyticus & $\begin{array}{l}\text { UV Radiations and N-methyl-N'-nitro-N-Nitro Guanidine } \\
\text { (NTG) }\end{array}$ & 1.4 folds & [173] \\
\hline
\end{tabular}

Table 3: Optimized parameters for microbial cellulase production through fermentation.

\begin{tabular}{|c|c|c|c|c|c|c|}
\hline \multirow{2}{*}{$\begin{array}{c}\text { Microbial } \\
\text { Strains }\end{array}$} & \multirow{2}{*}{$\begin{array}{c}\text { Fermentation } \\
\text { Process }\end{array}$} & \multicolumn{4}{|c|}{ Optimized Parameters } & \multirow{2}{*}{ Ref } \\
\hline & & $\mathrm{pH}$ & Temp & C Source & N Source & \\
\hline Pleurotus sapidas & Submerged & 5 & $25^{\circ} \mathrm{C}$ & Fructose & Beef Extract & {$[174]$} \\
\hline Aspergillus niger & Both Solid State and Submerged & 6 & $30^{\circ} \mathrm{C}$ & Lactose & Peptone & [175] \\
\hline P1 fungal Isolate & Solid State & 6 & $30^{\circ} \mathrm{C}$ & Lactose & Peptone & [176] \\
\hline Aspergillus sp. B11 & Solid State & 7 & $37^{\circ} \mathrm{C}$ & Banana Leaves & Tryptone & [177] \\
\hline Aspergillus flavus AT-2 & Solid State & 5.3 & $35^{\circ} \mathrm{C}$ & Wheat Straw & $\left(\mathrm{NH}_{4}\right)_{2} \mathrm{SO}_{4}$ & [178] \\
\hline Enhydrobacter sp. ACCA2 & Submerged & 6.5 & $30^{\circ} \mathrm{C}$ & CMC & Peptone and $\left(\mathrm{NH}_{4}\right)_{2} \mathrm{SO}_{4}$ & [179] \\
\hline Bacillus subtilis $\mathrm{K}-18$ & Submerged & 7 & $30^{\circ} \mathrm{C}$ & 2\% Potato peel & $1 \%$ yeast Extract & [180] \\
\hline Streptomyces sp. & Submerged & $7-7.5$ & $26^{\circ} \mathrm{C}$ & Meat Extract and Tryptone & Glucose and Cellobiose & [181] \\
\hline Mirococcus sp. & Submerged & 5 & $25^{\circ} \mathrm{C}$ & Yeast Extract and Tryptone & $\mathrm{CMC}$ & {$[182]$} \\
\hline
\end{tabular}

in industries. In order to further exploit the potential of wild type microorganisms, strain improvement is required which can modify or eliminate specific trait [35]. The commercial production can be enhanced by Recombinant DNA technology [11], Site directed Mutagenesis [2], Recombination Protoplast fusion [36] and Random Mutagenesis as explained in (Table 2) [37]. Immobilization of cellulase on any solid support is also one of method to improve the efficiency of catalytic activities of enzymes for the industrial applications.

\section{Genetic Recombination}

Strain improvement through genetically modifying the microbial strains via different molecular techniques, which has gained much importance [38].

\section{Recombinant DNA Technology}

The Recombinant DNA technology is applied to introduce novel characteristics in an organism by manipulating their genome through inserting or removing the genes or by modification of regulatory regions. The strain improvement through this technology involves the introduction of genes through vectors and desirable traits from different sources [39]. The specificity and yield of cellulase can be enhanced by recombinant DNA technology to insert the cellulases producing gene in the targeted microbial strains [40]. The cellulase production by Trichoderma reesei (filamentous fungi) was enhanced by recombinant DNA technology [41]. Similarly, the A. oryzae A4 specie isolated from soil was mutagenized through Recombinant DNA technology by inserting four cellulase genes (cel A, cel B, cel C and $\mathrm{Cel} D$ ) comprised the cellulase expression cassette. The increased secretion of cellulase will facilitate the degradation of cellulosic biomass and the conversion of end products [42].

\section{Site Directed Mutagenesis}

In site directed mutagenesis, the gene responsible for specific characteristic is manipulated through molecular tools that will 


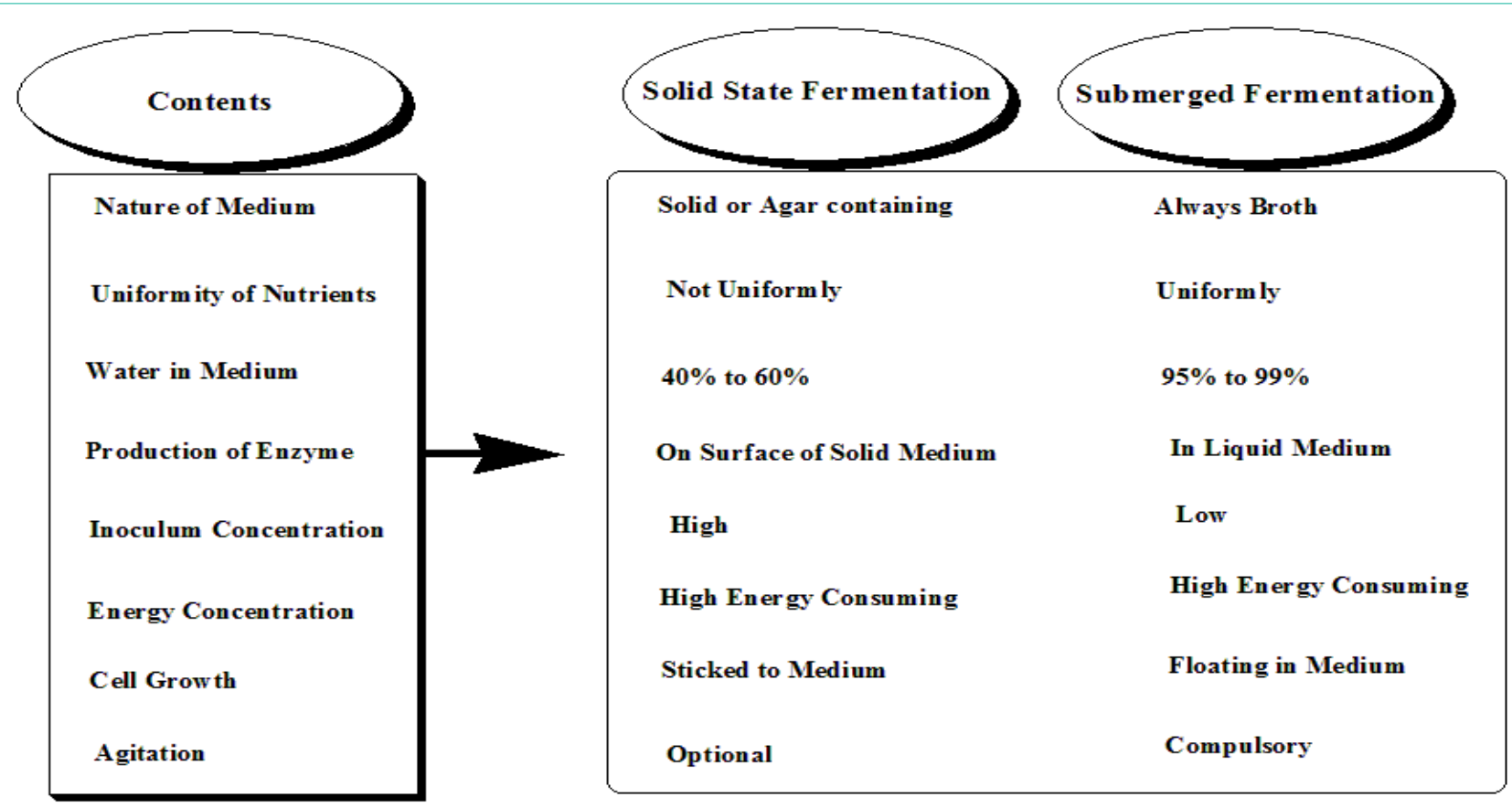

Figure 5: Comparison of physical and chemical conditions in solid state and submerged fermentation.

alternatively alter the function of that specific gene [43]. In this type of mutagenesis, the mutants are further improved through engineering, consequently the properties of enzymes such as temperature and $\mathrm{pH}$ profile, activity and thermo-stability will be enhanced. For the engineering of enzymes in directed evolution, the knowledge about the structure and function of enzymes, the enzyme-substrate interaction and catalysis is required [44]. Zhang et al. [45] improved the endoglucanases isolated from Thermotoga miritima through site directed mutagenesis. Similarly, Zhang et al. [46] also improved the $\beta$-galactosidase produced from Aspergillus candidus in order to reduce the galactose inhibition during hydrolysis of lactose.

\section{Protoplast Fusion}

Protoplast fusion is a recent technique for the strain improvement through which the desirable characteristics such as disease resistance, rapid growth, drought, heat and cold resistances, increasing protein quantities and for enhancing the industrially important products by fusion of protoplasts of two genetically different strains. Protoplast fusion is mostly used for the engineering of industrially important microorganisms and filamentous fungi [47]. This technique is nonspecific recombination method and involves the breakdown of cell wall, protoplast regeneration and finally fusion of intragenic, intragenic and intraspecific protoplasts through chemicals. Moreover, electric current can also be used for producing potential mutants having specialized characteristics and also gain importance in applied genetics $[48,49]$. The interspecific protoplast fusion between different fungal strains that have been already reported includes $A$. oryzae and A. sojae, A. fumigatus and A. nidulans, A. falvipes and Aspergillus $\mathrm{sp}$, Pencillum chrysogenum and Penicillum notatum. The protoplasts of Trichoderma harzianum and Aspergillus oryzae were fused for the enhanced production of chitanases [50]. The $\beta$-galactosidase production was improved by fusing the protoplasts of $A$. niger and
A. oryzae and the fusion was facilitated by polyethylene glycol, $\mathrm{CaCl}_{2}$ and $\mathrm{NaCl}[51]$.

\section{Random Mutagenesis}

The production of industrially important metabolites/enzymes can be shifted to desirable concentration and some new products can be produced by changing the pathways through mutagenizing the microbial strains. Some mutations can have detrimental effects and usually eliminated during screening while the potent mutants are selected during strain and process development by fermentation scientists. For random mutagenesis, the selected microbial strain is treated with mutagenic substance or radiations and after a desired $\log$ kill the survivors are selected and screened. The potent chemical mutagens for introducing random mutations includes; EMS (Ethyl methyl sulphonate), NTG (Nitrosoguandidne), HA (hydroxyl amine, MMS (Methylmethane sulphonate) while gamma radiations and ultra violet radiations are classified as effective mutagenic radiations [52]. Random mutagenesis or classical strain improvement is usually employed in food industries and involves the introduction of random mutations in the genome through ionizing radiations or different other mutagens, screening of mutants and selection of mutant possessing the desirable characteristic for the further use [35].

The strain improvement and selection of superior mutated strain for particular enzyme is the most painstaking effort. Vu et al. [38] reported the fungal strain improvement through repeated and sequential mutations for CMCase hyper-production by treatment with gamma-rays ( $\gamma$-rays) of Co [60], UV and NTG. Ghonemy et al. [12] reported that the cellulase production from A. oryzae can be enhanced by multi-step mutations strategy such that in first mutation the fungus is treated with ultraviolet radiations (UV) and chemical mutagen N-methyl-N-Nitro-N-Nitrosoguanidine (NTG) and in second mutation step the fungal strain is treated with 
ultraviolet radiations and ethidium bromide (Et-Br). Reddy et al. [53] mutagenized the $A$. niger by irradiating with UV and then treated with EMS (ethyl Methyl Sulphonate) for the enhanced production of cellulases. The improved strains can reduce the cost of the processes with increased productivity and may also possess some specialized desirable characteristics [54].

\section{Production of Cellulase through Fermentation Technology}

Cellulases enzyme can be produce from number of microorganisms such as yeast, fungi and bacteria. It can be produced in large quantity through fermentation technology [55]. To overcome the increasing demand for industrially important cellulases, the global production can be improved by improving the fermentation technology and augmentation of downstream processing for the recovery of purified cellulases in large amount [56]. The industrial production of cellulases can be carried out in both solid state fermentation and submerged fermentation [57]. Furthermore, according to Mahmoud et al the industrial production can be carried out in Submerged Fermentation (SmF), Solid State Fermentation (SSF) and Biofilm Fermentation (BF) (Figure 5) [58]. The cellulase activity can be determined by the standard protocol presented by Siddiqui et al [59]. One-unit cellulase activity was defined as the amount of enzyme required to release $1 \mu \mathrm{mol}$ of reducing sugar (glucose) per min from soluble cellulose at optimized conditions.

\section{Solid State Fermentation}

The fermentation in which microorganism are grown in lower amount of water for the production of industrially important products is known as solid state fermentation or SSF and was used for thousands of years in Western and Eastern countries [60]. The most attractive and promising technique for production of cellulases is solid state fermentation because it provides natural habitats to the fungi with minimum amount of water consequently results in the more fungal growth with higher enzyme yield. Moreover, it is preferred because of comparatively simpler technique, with lower substrate and energy utilization, and production of least amount of waste products [61]. Therefore, the down-stream processing will be comparatively easy. Cellulases produced by various microbial strains supplemented with different substrates in solid state fermentation is presented in (Table 3).

\section{Submerged Fermentation}

The other type of fermentation, which is utilized for the production of industrially important enzymes involve the culturing of microorganism in submerged or liquid media containing high amount of water named as Submerged Fermentation (Smf) [60]. However, submerged fermentation is advantageous because of simple instrumentation and easy recovery of product after fermentation including separation of biomass. The parameters such as scaling up, aeration, mixing, and water-soluble molecules content, temperature, $\mathrm{pH}$ and dissolve oxygen can be comparatively controlled easily [62]. The enzymes can be conventionally produced through submerged fermentation and is advantageous because of control and monitoring of environmental factors and easy handling [63]. Gamarra et al. [64] reported that the large scale cellulase production from filamentous fungal strains can be carried out on different carbon sources through both submerged and solid state fermentation. It is also reported that the properties of enzymes produced by same fungal strain may vary when grown in different fermentation processes such as the properties of cellulases produced by same filamentous fungi in solid state fermentation may vary from that in submerged fermentation [15].

\section{Biofilm Fermentation}

Similarly, the biofilm fermentation is the advanced forms of solid-state fermentation, in which microbial cells are physiologically adhere to one another. The biofilm fermentation process can be used for the production of cellulases, different metabolites and some other metabolites along with its major application in waste water treatment. However, this type of fermentation process is most common for bacterial strain rather than fungal strain [65]. By attachment with any solid surface, the physiology of fungal cells changes due to differential expression of genes. However, the physiology of filamentous fungal cells grow in biofilm fermentation differs from that in submerged fermentation. The biofilm formation of filamentous fungal cells is usually easy as they can naturally attached to any solid substrate. For the immobilization of fungal cells for the production of enzymes, commonly surface binding and entrapment techniques are used [66].

\section{Factors Affecting Cellulase Production}

The established approach for enhancing of the enzyme productivity and cost reduction at industrial level involves the designing of experiments for the optimization of physical and factors [67]. The production of cellulase including endoglucanase can be influenced by both physical parameters such as temperature, $\mathrm{pH}$ and moisture and chemical factors such as carbon, nitrogen and minerals. Among all chemical factors, carbon is the most important source that usually acts as a substrate and depends on the yield of enzyme. The substrate must be easily available and cost effective. The selection of appropriate and cheap carbon source, nutrient media, culture and optimization of conditions are required for the maximum production of Endoglucanase [68]. The optimization of physical (temperature and $\mathrm{pH}$ ) and Chemical (Carbon and Nitrogen sources) for cellulase production by bacterial and fungal strains is reported in (Table 3).

Hoa and Hung [69] optimized the chemical requirements (substrate, carbon, nitrogen and trace elements), and physical conditions (temperature, $\mathrm{pH}$, moisture content and incubation time) for the production of Endoglucanases from Aspergillus oryzae. It is reported that different parameters such as temperature, $\mathrm{pH}$ and inoculum size were optimized for the cellulase and pectinase enzymes produced by Aspergillus niger on corn cob (substrate). For the maximum production of cellulases from fungal strains, bagasse powder can also be used as a substrate. The physical (temperature, $\mathrm{pH}$ ) and chemical conditions (different substrates and other nutrients) for novel fungal strain Aspergillus tubingensis isolated from rotten tomato was optimized through response surface methodology [70,71]. Goyal et al. [72] also investigated the effects of temperature, $\mathrm{pH}$, incubation time, different substrates in variable concentrations (carbon source) and nitrogen sources on the maximum production of CM Cases from A. niger.

\section{Purification and Characterization of Cellulases}

Due to wide variety of applications, the cellulases must be 
Table 4: Purification of microbial cellulase.

\begin{tabular}{|c|c|c|c|c|c|c|}
\hline \multicolumn{2}{|r|}{ Microbial Strain } & $\begin{array}{l}\text { Ammonium Sulphate } \\
\text { Saturation (\%) }\end{array}$ & Purification Method & $\begin{array}{l}\text { Purification } \\
\text { Folds }\end{array}$ & $\begin{array}{l}\text { Recovery } \\
\text { (\%) }\end{array}$ & Ref \\
\hline \multirow{4}{*}{ Fungal } & Penicillium decumbens & $80 \%$ & Ion-exchange Chromatography & 4.3 & $42 \%$ & [1] \\
\hline & Schizophyllum Commune & $60 \%$ & $\begin{array}{l}\text { Ion-exchange Chromatography \& Gel-Filtration } \\
\text { Chromatography }\end{array}$ & $4 \& 3.7$ & $41-72.8 \%$ & [2] \\
\hline & Aspergillus terreus & $80-95 \%$ & $\begin{array}{l}\text { DEAD-Cellulase Chromatography Ultra Gel Column } \\
\text { Chromatography }\end{array}$ & 270 & $22.11 \%$ & [3] \\
\hline & Aspergillus terreus & --1---- & Ion-exchange Chromatography & 7.6 & $82.20 \%$ & [4] \\
\hline \multirow{4}{*}{ Bacterial } & $\begin{array}{l}\text { Pseudomonas Fluorescens } \\
\text { (Wild type) }\end{array}$ & $90 \%$ & Ion-exchange Chromatography \& Gel-Filtration & $24 \& 52$ & $44 \% \& 19 \%$ & [6] \\
\hline & Bacillus Vallismortis & $80 \%$ & Ion-exchange Chromatography \& Gel-Filtration & $11.6 \& 39.1$ & $\begin{array}{c}75.4 \% \& \\
28.8 \%\end{array}$ & [7] \\
\hline & Pseudomonas sp. & $40 \%$ & Anion-exchange Chromatography & 14.52 & $33.40 \%$ & [8] \\
\hline & Paenibacillus sp. & $80 \%$ & $\begin{array}{l}\text { DEAD-cellulose Column Chromatography \& CM- } \\
\text { cellulose Column Chromatography }\end{array}$ & $5.9 \& 9.7$ & $\begin{array}{c}78.9 \% \& \\
35.7 \%\end{array}$ & [9] \\
\hline
\end{tabular}

purified and characterized as this will removed contamination as well as enhance their activity for specific function. In a study conducted by Elshafei et al. [73] the endoglucanase from Aspergillus terrus was purified through acetone fractionation and Sepharose4B chromatographic column. Nehad et al. [74] reported that for better understanding the mechanism of hydrolysis of cellulose into end products, the cellulases purified and characterized after isolation through different techniques. The crude enzyme can be partially purified through ammonium sulphate saturation and then further purified through ion-exchange chromatography and highpressure liquid chromatography. Nguyen and Quyen purified the endoglucanase from Aspergillus oryzae by $65 \%$ ammonium sulphate saturation followed by dialysis and further purified by Sephadex G-100 column washed with $50 \mathrm{mM}$ potassium phosphate buffer of $\mathrm{pH}$ 7.5 [75].

The $\beta$-glucosidase produced by $A$. oryzae and $A$. niger fusants was characterized and purified by ammonium sulphate precipitation and ion-exchange and gel filtration chromatography using G-150 sephadex gel and the specific activity of enzyme was enhanced after purification. [51]. Mostly enzyme has their specific/optimum parameters at which it works properly and maximum. Above or below the optimum parameters such as $\mathrm{pH}$, temperature, the activity of enzyme declines. The purification methods of cellulase produced by different microbial strains and the folds and recovery obtained after purification is explained in (Table 4).

\section{Immobilization of Cellulase Enzyme}

An alternative to the soluble enzymes is the use of immobilized enzyme on a supporting material. Using suitable matrix for the purpose of enzyme immobilization was discovered in 1916. Various types of materials, ranging from natural to synthetic including synthetic polymers, inert, inorganic polymers and nanoparticles, are being used for immobilization. The attachments of enzymes to these supports enhance their stability/adoptability, selectivity, manoeuvrability and product recovery $[4,76,77]$. Furthermore, the recyclability of the immobilized enzymes reduces the cost of the production process [7880]. Immobilized enzymes can be employed in chemical, food and pharmaceutical, textile industries and found potential applications in pharmacology, agricultural sciences, cosmetology, bio medicines as a biosensor for the diagnosis of different diseases such as diabetes and as drug delivery system [81]. In industrial bioprocess large concentration of cellulases loading is required for the degradation of polymeric Cellulose. Thus, the degradation of cellulose into monomeric product can improve by immobilizing the cellulases on solid matrices which results in the improvement in thermal stability, reusability and efficiency. Therefore, cellulase immobilization is considered as very cost effective. The two most important factors that can affect the immobilization process include immobilization methods and immobilized solid matrices [82]. Recently in 2018, Benkun Qi and co-workers immobilized cellulase on MOFs (UIO66-NH) and reported that the process has improved the catalytic activity and stability of cellulase mainly in the harsh conditions of temperature and $\mathrm{pH}$. Due to improved catalytic activity the cellulases can be reused in multiple catalytic reactions as compared to soluble cellulases [83].

\section{Industrial Application of Cellulase}

Cellulases are the major industrial enzymes that play a key role in agriculture and Biotechnological industry. Cellulases enzymes are produced widely in lab and industrial scale for the different applications in food industry, improvement in animal feeds, fermentation technology, textile industry, detergents, cosmetics, pulp and paper industry, brewing and wine making, biomass refining, and laundry (Table 5) $[84,85]$. Cellulases have been used in detergent and soap industry to remove stains and in production of biofuel for transport by hydrolysis of agricultural waste to bioethanol $[38,86]$.

\section{Pulp and Paper Industry}

The use of enzymes in pulp and paper industry for the recycling of pulp so this is the key interest to overcome the limitations of other ways of recycling of pulp. Due to the limitations of other methods, the interest of using cellulases for the applications in pulp and paper has been increased since 1980s [87]. The cellulases are successfully used for the removal of ink and polluted particles without any damage to the strength and brightness of the paper. This enzyme also has been successfully used for the pulping, bleaching, bioremediation of waste that are produced as a raw material during processing and have also great application in enhancement of fibres [88-91]. The biomechanical pulping, grinding, and refining are the energy saving (20-40\%) process and lead to the improvement of sheet strength and brightness [91,92-98]. Cellulases treatment cleans the surface of fibres by removing the fines and peel off. The advantages of using cellulases 
Table 5: Industrial applications of cellulase.

\begin{tabular}{|c|c|c|}
\hline Industry & Process & Ref \\
\hline \multirow{3}{*}{$\begin{array}{l}\text { Pulp and } \\
\text { paper } \\
\text { industry }\end{array}$} & Recycling of pulp & [87] \\
\hline & Removal of ink and polluted particles; Bioremediation of waste & [88-91] \\
\hline & $\begin{array}{l}\text { Improvement of sheet strength and brightness; Cleans the surface of fibres; Improve the strength properties: Brightness: } \\
\text { Cleanliness: Fairness: Deinking; Reduce the chlorine requirement }\end{array}$ & {$[92-98,91]$} \\
\hline \multirow{2}{*}{$\begin{array}{l}\text { Bio-fuels } \\
\text { production }\end{array}$} & Production of biofuels and ethanol & {$[101]$} \\
\hline & Production of second and third generation biofuels & [99] \\
\hline \multirow{3}{*}{$\begin{array}{l}\text { Textile } \\
\text { industry }\end{array}$} & Wet processing & {$[103,104]$} \\
\hline & Bio stoning of jeans; Biopolishing, Removal of dyes: Improvement in softness & {$[106,105]$} \\
\hline & De-fibrillation of Lyocell; Bio-carbonization and Wool Scouring & {$[111,88,112-116]$} \\
\hline $\begin{array}{l}\text { Laundry and } \\
\text { detergent } \\
\text { industry }\end{array}$ & Used in detergents for the removal of dirt and for enhancing the glossier appearance, brightness and smoothness of the fabrics & [118] \\
\hline \multirow{3}{*}{$\begin{array}{l}\text { Food and } \\
\text { feed industry }\end{array}$} & $\begin{array}{l}\text { Improves the methods of stabilization, extraction of fruit and vegetable juices; Found productive by improving the colour and } \\
\text { texture }\end{array}$ & {$[88,120,121]$} \\
\hline & Decreases viscosity, improves flavour properties; Reduces the bitterness of citrus fruits; & {$[88,183,184,104,185]$} \\
\hline & Improve the animal feed by providing extra supplementary support for better digestion and also cause gain in the weight & {$[88,104,124]$} \\
\hline \multirow{2}{*}{$\begin{array}{l}\text { Agricultural } \\
\text { industries }\end{array}$} & $\begin{array}{l}\text { Degrade the cell wall of the plant pathogens and keep plant safe from dangerous diseases; Improves roots, crop yield, } \\
\text { germination of seed, plant growth }\end{array}$ & {$[88,107]$} \\
\hline & Improves soil quality thus it limited the use of mineral fertilizer & {$[126,127]$} \\
\hline $\begin{array}{l}\text { Treatment of } \\
\text { diseases }\end{array}$ & $\begin{array}{l}\text { Can be used for the diagnosis and treatment of many diseases like Phytobezoars, Blinding keratitis is and Granulomatous } \\
\text { Amoebic Encephalitis }\end{array}$ & {$[129,128]$} \\
\hline $\begin{array}{l}\text { Waste } \\
\text { management }\end{array}$ & $\begin{array}{l}\text { By utilizing cellulosic wastes, it converts them into valuable products; Cellulosic waste can also be used as a Carbon source } \\
\text { in fermentation process }\end{array}$ & [130] \\
\hline \multirow[b]{2}{*}{$\begin{array}{l}\text { Flavonoid's } \\
\text { extraction }\end{array}$} & Used in the isolation of carotenoids and other flavonoids & [131] \\
\hline & $\begin{array}{l}\text { These flavonoids have applications in pharmaceutical, cosmetics and nutraceutical industries due to their anti-cancerous, } \\
\text { anti-oxidant, anti-mutagenic, anti-aging and anti-inflammatory properties; Also used in the treatment of many diseases such as } \\
\text { Alzheimer's disease, Cardiovascular disease, Atherosclerosis and many age-related diseases. }\end{array}$ & {$[132,133]$} \\
\hline $\begin{array}{l}\text { Research } \\
\text { purposes }\end{array}$ & Useful for studying single cell proteins: In plant studies such as metabolic and genomics; Virology; For the isolation of protoplast & [71] \\
\hline
\end{tabular}

enzymes in pulp and paper industry are, to limit the alkali usage and reduces the fine particles, improve the strength properties, the brightness, cleanliness, fairness, deinking and the main advantage of application of cellulases in pulp and paper industry is that it reduce the chlorine requirement which control the environmental impact [91,92-98].

\section{Bio-Fuels Production}

Cellulases have also found its potential application in the production of biofuels and ethanol. At industrial level the cellulases hydrolyse the fermentable sugars in the cellulosic and lignocellulose biomass and convert them into biofuels [99] by the action of cellulases enzyme system composed of endoglucanase, $\beta$-glucosidase and exoglucanase [100]. The demand for renewable energy sources is increasing day by day due to the depletion of naturally available biofuels. Therefore, the thirst for the cellulases production at commercial scale is also increased because of its application in the production of second and third generation biofuels [101]. However if the ethanol becomes the transportation fuel, then cellulases will be the major required industrial enzyme in the world market due to its potential role in the ethanol production by degradation of lignocellulose biomass [102].

\section{Textile Industry}

Cellulases enzymes have wide applications in textile for wet processing [103,104], bio-stoning of jeans, bio-polishing, removal of dyes, improvement in softness, removal of fuzz from surface of fibres [105], reduce formation of pill, enhancing colour of fibres without need of chemical coating [106], improve brightness, biofinishing [107] bio-stonewashing, bio-scouring [108,109], defibrillation of Lyocell [110], bio-carbonization and Wool Scouring [108]. Cellulases enzymes are used for bio-stoning which limited the abrasives washing, Blue jeans or denim garments have a great value in market from a few years but washing these garments from chemical treatment effects their shining and down their market. The alternative of washing from chemicals is enzymes processing from bio stoning which is also called bio stone washing. The use of cellulases for bio stone washing removes the dyes from the surface of fabrics and makes them to give look beautiful and shaded without damaging their strength $[88,111-116]$. The major advantages of using cellulase enzymes in textile industry are to improve shine and appearance. This process is permanent, environment friendly, highly productive, does not require intensive work, shorter time process, no heavy machinery required, fabrics give beautiful look and also the enzyme treatment is economical in comparison of other chemical treatment $[88,117,116]$.

\section{Laundry and Detergent Industry}

Cellulases in combination with lipases and proteases are used in detergents and used for the removal of dirt and for enhancing the glossier appearance, brightness and smoothness of the fabrics [118]. The cellulases produced from Bacillus were also used in detergent and found that it restores their colour, improves softness and damage was negligible. Nowadays liquid laundry detergents have high market value and they improve the stability. Its components are 
anionic surfactants, protease, cellulases, boric acid and citric acid etc. Cellulases degrades the cellulose elements/molecules and remove the roughness from the surface and give smoother look [119,104].

\section{Food and Feed Industry}

Cellulases have a key role in food biotechnology industry to improve the methods of stabilization, extraction of fruit and vegetable juices. The cellulases enzyme with the combination of other important enzymes are used in food processing industry to improve the extraction and clarification methods of vegetable and fruit juices and they also play role to increase the yield of juice without too much capital investment $[88,120,121]$. The cellulases have potential to improve the animal feed and their performance [122]. The nutritional value of agriculture silage and grain feed has improved by treating with cellulases and xylanase. Cellulases enzyme also remove antinutritional element factors and using of cellulases enzyme into animal feed also provide extra supplementary support for better digestion [123]. The supplementation of enzymes including cellulases with animal feed cause to gain weight and become healthy. The digestion and absorption of feed materials are improved by addition of enzyme including cellulases into feed, then it make the digestive process very proper and it help them to be healthy by gaining weight $[88,104,124]$.

\section{Agricultural Industries}

Cellulases alone or in combination with pectinase, hemicelluloses have remarkable and diverse application in agriculture industries. These enzyme control diseases that are associated with plants and enhance yield of crops [88,107]. Cellulases with combination of related enzymes degrade the cell wall of the pathogens that cause disease to plant thus it keeps plant safe from dangerous diseases. $\beta$-Glucosidase is the key enzyme which play a great role in degrading the cell wall of plant pathogens [125]. Cellulolytic fungi also play role to improve roots, crop yield, germination of seed, plant growth. Cellulases improve soil quality thus it limited the use of mineral fertilizer [126,127].

\section{Treatment of Diseases}

Fungal and bacterial cellulases are used in the treatment of diseases such as Phytobezoars (caused by ingestion of plant that is indigestible and blocked gastrointestinal tract), blinding keratitisis and granulomatous amoebic encephalitis (caused by Acanthamoeba) by degrading the cell wall of plants and biofilms [128]. The immobilized cellulases can be used as a bioreactor for enzyme related (Enzyme deficient diseases), use as a sensor for bioremediation and analytical flow system and can be used for the diagnosis and treatment of many diseases in the medical field directly or indirectly. The cellulases either individually or in enzyme cocktail form can be used in the treatment of many pathogenic diseases by disrupting the cellular membrane [129].

\section{Waste Management}

Cellulases also play key role in the waste management by utilizing forests, agricultural and industrial cellulosic wastes and converted into valuable products. The cellulosic waste can be used as a carbon source in fermentation process and consequently produce food and feed products, enzymes, organic acids, biofuels etc [130].

\section{Flavonoids Fxtraction}

Cellulases are also used in the isolation of carotenoids and other flavonoids from flowers used as colouring agents in the food industries [131]. Flavonoids are low molecular weight secondary metabolites produced in plants, vegetables, flowers and also present in some beverages and present in variable structures. The flavonoids also found potential applications in pharmaceutical, cosmetics and nutraceutical industries due to their anti-cancerous, anti-oxidant, anti-mutagenic, anti-aging and anti-inflammatory properties. Flavonoids are also efficient in inducing enzyme systems in humans that are involved in providing protection against bacterial and viral infections. Moreover, these biological active molecules are also used in the treatment of many diseases such as Alzheimer's disease, cardiovascular disease, atherosclerosis and many age related diseases $[132,133]$. Haung et al. [134] reported the extraction of flavonoids from medicinal plant Illicium verum by cellulase-ultrasonic assisted technology. Chen et al. [135] also reported that cellulases involve in the modification of flavonoids by trans-glycosylation as well as also assisted in the extraction of the modified pigments from the plants (Ginkgo biloba) by degrading the cell wall.

\section{Research Purposes}

Through the advancements in molecular biology cellulases also play key role in academic and industrial research. Cellulases are useful for studying single cell proteins and in plant studies such as metabolic and genomics, virology and in the development of hybrids and different varieties of plants by protoplast fusion. For the isolation of protoplast, the cellulases are used for the degradation of cellulose in plant cell wall [71].

\section{Conclusion}

Cellulases production from microorganism is gaining attention worldwide due to its increasing demand. Therefore, extensive research has been done in screening potent hyper producers of cellulases and already conquered the world enzyme global market to great extent. Cellulases can be produced from microbial strains through solid state and submerged fermentation processes at industrial scale by optimizing temperature, $\mathrm{pH}$ and nutritional requirements of growth media. Furthermore, microbial strains can be improved through mutagenic treatments (chemical and physical mutagens) for enhancing the production of cellulases. The stability and recyclability of cellulases can be enhanced through immobilization on solid supports. Cellulases has immense potential applications in various industries such as food and feed, laundry and detergents, paper and pulp, textile, biofuels and agriculture industries. Moreover, it is also employed for research purposes and in the treatment of diseases. Further advancements in biotechnology and microbiology are still needed to unlock the potential capabilities of cellulases.

\section{References}

1. Karigar CS, Rao SS. Role of microbial enzymes in the bioremediation of pollutants: a review. Enzyme res. 2011.

2. Koeller KM, Wong C-H. Enzymes for chemical synthesis. Nature. 2001; 409: 232.

3. Kumari A, Kayastha AM. Immobilization of soybean (Glycine max) $\alpha$-amylase onto Chitosan and Amberlite MB-150 beads: optimization and characterization. Journal of Molecular Catalysis B: Enzymatic. 2011; 69 : 
8-14

4. An H, Li M, Gao J, et al. Incorporation of biomolecules in Metal-Organic Frameworks for advanced applications. Coordination Chemistry Reviews. 2019; 384: 90-106.

5. Avendano KA, Anguiano M, Lopez CE, et al. Microbial enzymes applications in food processing. Agro Food Ind Hi Tech. 2016; 27: 63-67.

6. Chen S, Jiang K, Lou Z, et al. Recent Developments in Graphene-Based Tactile Sensors and E-Skins. Advanced Materials Technologies. 2018; 3 1700248.

7. Chen $\mathrm{H}$. Chemical composition and structure of natural lignocellulose Biotechnology of lignocellulose. Springer. 2014; 25-71.

8. Shuhui Y. Plant fiber chemistry. Beijing: China Light Industry Press. 2001; vol.,

9. Wu B, Zheng S, Pedroso MM, et al. Processivity and enzymatic mechanism of a multifunctional family 5 endoglucanase from Bacillus subtilis BS- 5 with potential applications in the saccharification of cellulosic substrates. Biotechnol Biofuels. 2018; 11: 20.

10. Bhardwaj SK, Sharma AL, Bhardwaj N, et al. TCNQ-doped Cu-metal organic framework as a novel conductometric immunosensing platform for the quantification of prostate cancer antigen. Sensors and Actuators B: Chemical. 2017; 240: 10-17.

11. Zhou J, Tian G, Zeng L, et al. Nanoscaled Metal-Organic Frameworks for Biosensing, Imaging, and Cancer Therapy. Advanced healthcare materials. 2018; 7: 1800022

12. Koklioti M, Tagmatarchis N. Metal Nanoclusters for Biosensing and Drug Delivery Applications. Drug Delivery Nanosystems: From Bioinspiration and Biomimetics to Clinical Applications. 2019; 223.

13. Pacala S, Socolow R. Stabilization wedges: solving the climate problem for the next 50 years with current technologies. Science. 2004; 305: 968-972.

14. Payne CM, Knott BC, Mayes HB, et al. Fungal cellulases. Chem reviews. 2015; 115: 1308-1448.

15. Dai H, Lü W, Zuo X, et al. A novel biosensor based on boronic acid functionalized metal-organic frameworks for the determination of hydrogen peroxide released from living cells. Biosensors and Bioelectronics. 2017; 95 131-137.

16. Ling $P$, Lei $J$, Zhang $L$, et al. Porphyrin-encapsulated metal-organic frameworks as mimetic catalysts for electrochemical DNA sensing via allosteric switch of hairpin DNA. Analytical chemistry. 2015; 87: 3957-3963.

17. Wang H-S. Metal-organic frameworks for biosensing and bioimaging applications. Coordination Chemistry Reviews. 2017; 349: 139-155.

18. Ergun R, Guo J, Huebner-Keese B. Cellulose. 2016.

19. Aden A, Foust T. Technoeconomic analysis of the dilute sulfuric acid and enzymatic hydrolysis process for the conversion of corn stover to ethanol. Cellulose. 2009; 16: 535-545.

20. Davis R, Tao L, Tan E, et al. Process design and economics for the conversion of lignocellulosic biomass to hydrocarbons: dilute-acid and enzymatic deconstruction of biomass to sugars and biological conversion of sugars to hydrocarbons. National Renewable Energy Lab.(NREL), Golden, CO (United States). 2013.

21. Humbird D, Davis $R$, Tao $L$, et al. Process design and economics for biochemical conversion of lignocellulosic biomass to ethanol: dilute-acid pretreatment and enzymatic hydrolysis of corn stover. National Renewable Energy Lab.(NREL), Golden, CO (United States). 2011.

22. Lynd LR, Weimer PJ, Van Zyl WH, et al. Microbial cellulose utilization fundamentals and biotechnology. Microbiol Mol Biol Rev. 2002; 66: 506-577.

23. Yennamalli RM, Rader AJ, Kenny AJ, et al. Endoglucanases: insights into thermostability for biofuel applications. Biotech Biofuels. 2013; 6: 136.

24. Annamalai N, Rajeswari MV, Elayaraja S, et al. Thermostable, haloalkaline cellulase from Bacillus halodurans CAS 1 by conversion of lignocellulosic wastes. Carbohydr Polym. 2013; 94: 409-415.
25. Bayer EA, Belaich J-P, Shoham $Y$, et al. The cellulosomes: multienzyme machines for degradation of plant cell wall polysaccharides. Annu Rev Microbiol. 2004; 58: 521-554

26. van den Brink J, de Vries RP. Fungal enzyme sets for plant polysaccharide degradation. Appl Microbiol Biotechnol. 2011: 91: 1477.

27. Xi J, Du W, Zhong L. 2013. Probing the interaction between cellulose and cellulase with a nanomechanical sensor, Cellulose-Medical, Pharmaceutical and Electronic Applications. IntechOpen.

28. Qin F-X, Jia S-Y, Wang F-F, et al. Hemin@ metal-organic framework with peroxidase-like activity and its application to glucose detection. Catalysis Science \& Technology. 2013; 3: 2761-2768.

29. Falcaro P, Ricco R, Yazdi A, et al. Application of metal and metal oxide nanoparticles@ MOFs. Coordination Chemistry Reviews. 2016; 307: 237254

30. Bruen D, Delaney C, Florea L, et al. Glucose sensing for diabetes monitoring recent developments. Sensors. 2017; 17: 1866.

31. Henrissat B. A classification of glycosyl hydrolases based on amino acid sequence similarities. Biochem J. 1991; 280: 309-316.

32. Sher $H$, Faheem M, Ghani $A$, et al. Optimization of cellulase enzyme production from aspergillus oryzae For industrial applications. World J Bio and Biotech. 2017; 2: 155-158.

33. Shahbazi S, Ispareh K, Karimi M, et al. Gamma and UV radiation induced mutagenesis in Trichoderma reesei to enhance cellulases enzyme activity. International Journal of Farming and Allied Science. 2014; 3:543-554.

34. Yang $\mathrm{P}$, Zhang $\mathrm{H}$, Cao L, et al. Construction of Aspergillus niger integrated with cellulase gene from Ampullaria gigas Spix for improved enzyme production and saccharification of alkaline-pretreated rice straw. 3 Biotech. 2016; 6: 236.

35. Derkx PM, Janzen T, Sørensen KI, et al. The art of strain improvement of industrial lactic acid bacteria without the use of recombinant DNA technology. BioMed Central. 2020.

36. UrraCa J. Molecularly Imprinted Polymer-based Optical Chemosensors for Selective Chemical Determinations. Molecularly Imprinted Polymers for Analytical Chemistry Applications. 2018; 28: 227.

37. Xu M, Yuan S, Chen X-Y, et al. Two-dimensional metal-organic framework Nanosheets as an enzyme inhibitor: modulation of the a-chymotrypsin activity. Journal of the American Chemical Society. 2017; 139: 8312-8319.

38. Vu VH, Pham TA, Kim K. Fungal strain improvement for cellulase production using repeated and sequential mutagenesis. Mycobiology. 2009; 37: $267-$ 271.

39. Khan S, Ullah MW, Siddique R, et al. Role of recombinant DNA technology to improve life. Int J Genomics. 2016; 2016.

40. Uddin SN, Hasan A, Anower M, et al. Commercial Enzymes Production by Recombinant DNA Technology: A Conceptual Works. Pak J Biol Sci. 2005 8: 345-355.

41. Qian Y, Zhong L, Hou Y, et al. Characterization and strain improvement of a hypercellulytic variant, Trichoderma reesei SN1, by genetic engineering for optimized cellulase production in biomass conversion improvement. Front Microbiol. 2016; 7: 1349

42. Lin $\mathrm{H}$, Wang $\mathrm{Q}$, Shen $\mathrm{Q}$, et al. Engineering Aspergillus oryzae $\mathrm{A}-4$ through the chromosomal insertion of foreign cellulase expression cassette to improve conversion of cellulosic biomass into lipids. PloS one. 2014: 9.

43. Pal N, Soni SK. Development of cellulolytic thermotolerant fungal strain. Genetic and Metabolic Engineering for Improved Biofuel Production from Lignocellulosic Biomass, $1^{\text {st }}$ ed. Elsevier. 2020; 137-142.

44. Liu M, Xie W, Xu H, et al. Directed evolution of an exoglucanase facilitated by a co-expressed $\beta$-glucosidase and construction of a whole engineered cellulase system in Escherichia coli. Biotechnol Lett. 2014: 36: 1801-1807.

45. Zhang J, Shi H, Xu L, et al. Site-directed mutagenesis of a hyperthermophilic endoglucanase Cel12B from Thermotoga maritima based on rational design. 
PloS one. 2015: 10

46. Zhang Z, Zhang F, Song L, et al. Site-directed mutation of $\beta$-galactosidase from Aspergillus candidus to reduce galactose inhibition in lactose hydrolysis. 3 Biotech. 2018: 8: 452.

47. Verma N, Bansal M, Kumar V. Protoplast fusion technology and its biotechnological applications. Chem Eng Trans. 2008; 14: 113-120.

48. Muralidhar R, Panda T. Fungal protoplast fusion-a revisit. Bioprocess Eng 2000; 22: 429-431.

49. Parani K, Eyini M. Strain improvement through protoplast fusion for enhanced coffee pulp degradation. Afr J Basic Appl Sci. 2010; 2: 37-41.

50. Patil N, Patil S, Govindwar SP, et al. Molecular characterization of intergeneric hybrid between $A$ spergillus oryzae and T richoderma harzianum by protoplast fusion. J Appl Microbiol. 2015; 118: 390-398.

51. Zhu F-M, Du B, Gao H-S, et al. Purification and characterization of an intracellular $\beta$-glucosidase from the protoplast fusant of Aspergillus oryzae and Aspergillus niger. Appl Biochem Microbiol. 2010; 46: 626-632.

52. Adrio JL, Demain AL. Genetic improvement of processes yielding microbia products. FEMS Microbiology Review. 2006; 30: 187-214.

53. Kreno LE, Leong K, Farha OK, et al. Metal-organic framework materials as chemical sensors. Chemical reviews. 2012; 112: 1105-1125.

54. Karanam SK, Medicherla NR. Enhanced lipase production by mutation induced Aspergillus japonicus. Afr J Biotechnol. 2008; 7.

55. Gautam S, Bundela P, Pandey A, et al. Optimization for the production of cellulase enzyme from municipal solid waste residue by two novel cellulolytic fungi. Biotechol Res Int. 2011; 2011.

56. Wong-Foy AG, Matzger AJ, Yaghi OM. Exceptional H2 saturation uptake in microporous metal- organic frameworks. Journal of the American Chemical Society. 2006; 128: 3494-3495.

57. Saqib AA, Hassan M, Khan NF, et al. Thermostability of crude endoglucanase from Aspergillus fumigatus grown under Solid State Fermentation (SSF) and Submerged Fermentation (SmF). Process Biochem. 2010; 45: 641-646.

58. Al-Maqtari QA, Waleed A, Mahdi AA. Microbial enzymes produced by fermentation and their applications in the food industry-A review. Int J Agric Innov Res. 2019; 8: 62-82.

59. Siddiqui KS, Saqib AAN, Rashid MH, et al. Carboxyl group modification significantly altered the kinetic properties of purified carboxymethylcellulase from Aspergillus niger. Enzyme and Microbial Technology. 2000; 27: 467 474.

60. Soccol CR, da Costa ESF, Letti LAJ, et al. Recent developments and innovations in solid state fermentation. Biotechnol Res Innov. 2017; 1: 52 71.

61. Ohara A, SANTOS JGd, ANGELOTTI JAF, et al. A multicomponent system based on a blend of agroindustrial wastes for the simultaneous production of industrially applicable enzymes by solid-state fermentation. J Food Sci Technol. 2018; 38: 131-137.

62. Farinas CS, Scarpelini L, Miranda E, et al. Evaluation of operational parameters on the precipitation of endoglucanase and xylanase produced by solid state fermentation of Aspergillus niger. Braz J Chem Eng. 2011; 28: $17-26$

63. Mrudula S, Murugammal R. Production of cellulase by Aspergillus niger under submerged and solid state fermentation using coir waste as a substrate. Braz J Microbiol. 2011; 42: 1119-1127.

64. Gamarra NN, Villena GK, Gutiérrez-Correa M. Cellulase production by Aspergillus niger in biofilm, solid-state, and submerged fermentations. Appl Micrbiol Biotechnol. 2010; 87: 545-551.

65. Villena G, Gutiérrez-Correa M. Morphological patterns of Aspergillus niger biofilms and pellets related to lignocellulolytic enzyme productivities. Lett Appl Microbiol. 2007; 45: 231-237.

66. Villena G, Gutiérrez-Correa M. Production of cellulase by Aspergillus niger biofilms developed on polyester cloth. Lett Appl Microbiol. 2006; 43: 262268.

67. Singh S, Bajaj BK. Bioprocess optimization for production of thermoalkalistable protease from Bacillus subtilis $\mathrm{K}-1$ under solid-state fermentation. Prep Biochem Biotech. 2016; 46: 717-724.

68. Sher H, Faheem M, Ghani A, et al. Optimization of cellulase enzyme production from aspergillus oryzae For industrial applications. World $\mathrm{J}$ Bio Biotechnol. 2017; 2: 155-158

69. Hoa B, Hung P. Optimization of nutritional composition and fermentation conditions for cellulase and pectinase production by Aspergillus oryzae using response surface methodology. Int Food Res J. 2013; 20: 3269.

70. Imran M, Anwar Z, Irshad M, et al. Cellulase production from species of fungi and bacteria from agricultural wastes and its utilization in industry: a review. Adv Enzyme Res. 2016; 4: 44-55.

71. Imran M, Anwar Z, Irshad M, et al. Optimization of cellulase production from a novel strain of Aspergillus tubingensis IMMIS2 through response surface methodology. Biocatal Agric Biotechnol. 2017; 12: 191-198.

72. Goyal V, Aggarwal NK, Bhuwal A, et al. Optimization of CMCase production by Aspergillus niger BK01 using pretreated rice straw under submerged fermentation. Octa J Biosci. 2014; 2.

73. Elshafei AM, Hassan MM, Haroun BM, et al. Purification and properties of an endoglucanase of Aspergillus terreus DSM 826. J Basic Microbiol. 2009; 49: 426-432.

74. Nehad E, Yoness M, Reem A. Optimization and purification of cellulase produced by Penicillium decumbens and its application. Egypt Pharmaceut J. 2019; 18: 391

75. Nguyen HQ, Quyen DT. Purification and properties of an endoglucanase from Aspergillus oryzae VTCC-F045. Aust J Basic Appl Sci. 2010; 4: 62176222.

76. Girigowda K, Mulimani V. Hydrolysis of galacto-oligosaccharides in soymilk by $\mathrm{k}$-carrageenan-entrapped $\alpha$-galactosidase from Aspergillus oryzae. World J Microbiol Biotechnol. 2006; 22: 437-442.

77. Li C, Jiang S, Zhao X, et al. Co-immobilization of enzymes and magnetic nanoparticles by metal-nucleotide hydrogelnanofibers for improving stability and recycling. Molecul. 2017; 22: 179 .

78. Moléculaire Uidbedb. Report of the Commission on Enzymes of the International Union of Biochemistry. Pergamon. 1961.

79. Sheldon RA, van Pelt S. Enzyme immobilisation in biocatalysis: why, what and how. Chem Soc Rev. 2013; 42: 6223-6235.

80. Xiangli Q, Zhe L, Zhiwei L, et al. Immobilization of activated sludge in poly (ethylene glycol) by UV technology and its application in micro-polluted wastewater. Biochem Eng J. 2010; 50: 71-76.

81. Helm M, Motorin Y. Detecting RNA modifications in the epitranscriptome: predict and validate. Nature Reviews Genetics. 2017; 18: 275-291.

82. Mohamad NR, Marzuki NHC, Buang NA, et al. An overview of technologies for immobilization of enzymes and surface analysis techniques for immobilized enzymes. Biotechnol Biotechnol Equip. 2015; 29: 205-220.

83. Qi B, Luo J, Wan Y. Immobilization of cellulase on a core-shell structured metal-organic framework composites: Better inhibitors tolerance and easier recycling. Bioresource technology. 2018; 268: 577-582.

84. Khoshnevisan $\mathrm{K}$, Vakhshiteh $\mathrm{F}$, Barkhi M, et al. Immobilization of cellulase enzyme onto magnetic nanoparticles: Applications and recent advances. Mol Catal. 2017; 442: 66-73.

85. Kuhad RC, Gupta R, Singh A. Microbial cellulases and their industrial applications. Enzyme res. 2011; 2011.

86. Camassola M, Dillon AJ. Biological pretreatment of sugar cane bagasse for the production of cellulases and xylanases by Penicillium echinulatum. Industrial Crops and Products. 2009; 29: 642-647.

87. Mai $\mathrm{C}$, Kües $\mathrm{U}$, Militz $\mathrm{H}$. Biotechnology in the wood industry. Appl Microbiol 
Biotechnol. 2004; 63: 477-494

88. Bhat M. Cellulases and related enzymes in biotechnology. Biotechnol Adv. 2000; 18: 355-383.

89. Efrati Z, Talaeipour M, Khakifirouz A, et al. Impact of cellulase enzyme treatment on strength, morphology and crystallinity of deinked pulp. Cell Chem Technol. 2013; 47: 547-551.

90. Kuhad RC, Mehta G, Gupta R, et al. Fed batch enzymatic saccharification of newspaper cellulosics improves the sugar content in the hydrolysates and eventually the ethanol fermentation by Saccharomyces cerevisiae. Biomass and Bioenergy. 2010; 34: 1189-1194.

91. Singh A, Sharma R. Mycoremediation an eco-friendly approach for the degradation of cellulosic wastes from paper industry with the help of cellulases and hemicellulase activity to minimize the industrial pollution. Int $J$ Environ Eng Manag. 2013; 4: 199-206.

92. Efrati Z, Talaeipour M, Khakifirouz A, et al. Impact of cellulase enzyme treatment on strength, morphology and crystallinity of deinked pulp. Cellulose Chemistry and Technology. 2013; 47: 547-551.

93. Jeffries TW, Klungness $\mathrm{JH}$, Sykes MS, et al. Comparison of enzyme: enhanced with conventional deinking of xerographic and laser: printed paper. Tappi J. 1994.

94. Kantelinen A, Jokinen O, Sarkki M, et al. Effects of enzymes on the stability of colloidal pitch. 2019; 605-612.

95. Kuhad RC, Mehta G, Gupta R, et al. Fed batch enzymatic saccharification of newspaper cellulosics improves the sugar content in the hydrolysates and eventually the ethanol fermentation by Saccharomyces cerevisiae. Biomass and Bioen. 2010; 34: 1189-1194.

96. Lee C, Darah I, Ibrahim C. Enzymatic deinking of laser printed office waste papers: some governing parameters on deinking efficiency. Bioresour Technol. 2007; 98: 1684-1689.

97. Pelach M, Pastor F, Puig J, et al. Enzymic deinking of old newspapers with cellulase. Process Biochemistry. 2003; 38: 1063-1067.

98. Pere J, Puolakka A, Nousiainen P, et al. Action of purified Trichoderma reesei cellulases on cotton fibers and yarn. Journal of Biotechnology. 2001; 89: 247-255.

99. Kumar R, Tabatabaei M, Karimi K, et al. Recent updates on lignocellulosic biomass derived ethanol-A review. Biofuel Res J. 2016; 3: 347-356.

100. Srivastava N, Srivastava M, Mishra P, et al. Application of Cellulases in Biofuels Industries: An Overview. Journal of Biofuels and Bioenergy. 2015 1: $55-63$.

101. Pandey A, Srivastava N, Sinha P. Optimization of hydrogen production by Rhodobacter sphaeroides NMBL-01. Biomass Bioenerg. 2012; 37: 251-256.

102. Singhania RR, Sukumaran RK, Patel AK, et al. Advancement and comparative profiles in the production technologies using solid-state and submerged fermentation for microbial cellulases. Enzyme Microb Tech. 2010; 46: 541-549.

103. Hebeish A, Ibrahim N. The impact of frontier sciences on textile industry Colourage. 2007 ; $54:$ 41-55.

104. Karmakar M, Ray R. Current trends in research and application of microbial cellulases. Res J Microbiol. 2011; 6: 41-53.

105. Sreenath HK, Shah AB, Yang VW, et al. Enzymatic polishing of jute/cotton blended fabrics. J Biosci Bioeng. 1996; 81: 18-20.

106. Galante Y, De Conti A, Monteverdi R. Application of Trichoderma enzymes in the textile industry. Trichoderma \& Gliocladium. 2014; 2: 311-325.

107. Kuhad RC, Gupta R, Singh A. Microbial cellulases and their industrial applications. Enzyme research. 2011; 2011

108. Mojsov K. Application of enzymes in the textile industry: a review. 2011.

109. Morgado J, Cavaco-Paulo A, Rousselle M-A. Enzymatic treatment of lyocellclarification of depilling mechanisms. Text Res J. 2000; 70: 696-699.
110. Araujo R, Casal M, Cavaco-Paulo A. Application of enzymes for textile fibres processing. Biocatal Biotransformation. 2008; 26: 332-349.

111. Anish R, Rahman MS, Rao M. Application of cellulases from an alkalothermophilic Thermomonospora $\mathrm{sp}$. in biopolishing of denims. Biotechnol Bioeng. 2007; 96: 48-56.

112. Heikinheimo L, Buchert J, Miettinen-Oinonen A, et al. Treating denim fabrics with Trichoderma reesei cellulases. Text Res J. 2000; 70: 969-973.

113. Miettinen-Oinonen A, Suominen P. Enhanced production of Trichoderma reesei endoglucanases and use of the new cellulase preparations in producing the stonewashed effect on denim fabric. Appl Environ Microbiol. 2002I; 68: 3956-3964.

114. Montazer M, Maryan AS. Influences of different enzymatic treatment on denim garment. Biotechnol Appl Biochem. 2010; 160: 2114-2128.

115. Pazarlioğlu NK, Sariişik M, Telefoncu A. Treating denim fabrics with immobilized commercial cellulases. Process Bioch. 2005; 40: 767-771.

116. Shah S. Chemistry and application of cellulase in textile wet processing. Int J Eng Sci. 2013; 2278.

117. Araujo R, Casal M, Cavaco-Paulo A. Application of enzymes for textile fibres processing. Biocatalysis and Biotransformation. 2008; 26: 332-349.

118. Karmakar M, Ray RR. A statistical approach for optimization of simultaneous production of $\beta$-glucosidase and endoglucanase by Rhizopus oryzae from solid-state fermentation of water hyacinth using central composite design. Biotechnol Res Int. 2011; 2011.

119. Bettiol J-LP, Thoen CAJK. Alkaline detergent compositions comprising a specific cellulase. Google Patents. 2001.

120. De Carvalho LMJ, De Castro IM, Da Silva CAB. A study of retention of sugars in the process of clarification of pineapple juice (Ananas comosus, L. Merril) by micro-and ultra-filtration. J Food Eng. 2008; 87: 447-454.

121. Sukumaran RK, Singhania RR, Pandey A. Microbial cellulases-production, applications and challenges. 2005.

122. Dhiman T, Zaman M, Gimenez R, et al. Performance of dairy cows fed forage treated with fibrolytic enzymes prior to feeding. Anm Feed Sci Tech. 2002; 101: 115-125.

123. Ali S, Hall J, Soole KL, et al. Targeted expression of microbial cellulases in transgenic animals. Biotechnol Prog. 1995; 10: 279-293.

124. Shrivastava B, Thakur S, Khasa YP, et al. White-rot fungal conversion of wheat straw to energy rich cattle feed. Biodegradation. 2011; 22: 823-831.

125. Singh A, Kuhad RC, Ward OP. Industrial application of microbial cellulases. Lignocellulose Biotechnologgy: Future Prospects. 2007; 345-358.

126. Bailey B, DEN RL. Gliocladium on plant growth and resistance to pathogens Enzy, Biol Con. 2014; 2: 185

127. Lorito M, Hayes C, Di Pietro A, et al. Purification, characterization, and synergistic activity of a glucan 1, 3-beta-glucosidase and an $\mathrm{N}$-acetyl-betaglucosaminidase from Trichoderma harzianum. Phytopathol. 1994.

128. Singh R, Kumar M, Mittal A, et al. Microbial enzymes: industrial progress in 21 ${ }^{\text {st }}$ century. 3 Biotech. 2016; 6: 174.

129. Jayasekara S, Ratnayake R. Microbial Cellulases: An Overview and Applications. Cellulose. 2019; 84531.

130. Kuhad RC, Gupta R, Singh A. Microbial cellulases and their industrial applications. Enzyme Res. 2011; 2011.

131. Menendez E, Garcia-Fraile P, Rivas R. Biotechnological applications of bacterial cellulases. AIMS Bioeng. 2015; 2: 163

132. Kumar S, Pandey AK. Chemistry and biological activities of flavonoids: an overview. Sci World J. 2013; 2013.

133. Panche A, Diwan A, Chandra S. Flavonoids: an overview. J Nutr Sci. 2016; 5.

134. Huang D, Zhou X, Si J, et al. Studies on cellulase-ultrasonic assisted extraction technology for flavonoids from Illicium verum residues. Chem 
Cent J. 2016; 10: 56 .

135. Chen S, Xing X-H, Huang J-J, et al. Enzyme-assisted extraction of flavonoids from Ginkgo biloba leaves: Improvement effect of flavonol transglycosylation catalyzed by Penicillium decumbens cellulase. Enzyme Microb Tech. 2011 48: 100-105.

136. Devi MC, Kumar MS. Production, optimization and partial purification of cellulase by Aspergillus niger fermented with paper and timber sawmil industrial wastes. Journal of Microbiology and Biotechnology Research. 2012; 2: 120-128.

137. Legodi L, La Grange D, van Rensburg E, et al. Isolation of cellulose degrading fungi from decaying banana pseudostem and Strelitzia alba. Enzyme Research. 2019; 2019.

138. SANTOS TCD, Abreu Filho G, BRITO ARD, et al. Production and characterization of cellulolytic enzymes by Aspergillus niger and Rhizopus sp. by solid state fermentation of prickly pear. Revista Caatinga. 2016; 29 : 222-233.

139.PAULA CCD, MONTOYA QV, Meirelles LA, et al. High cellulolytic activities in filamentous fungi isolated from an extreme oligotrophic subterranean environment (Catão cave) in Brazil. Anais da Academia Brasileira de Ciências. 2019; 91: 3.

140. Ismail SA, Hassan AA. Optimizing the production of rice straw hydrolytic cellulase under solid-state fermentation using Aspergillus terreus RS2. Egyptian Pharmaceutical Journal. 2020; 19: 7

141. Cheng $Y$, Song $X$, Qin $Y$, et al. Genome shuffling improves production of cellulase by Penicillium decumbens JUA10. Journal of applied microbiology. 2009; 107: 1837-1846.

142.de Castro AM, de Carvalho MLdA, Leite SGF, et al. Cellulases from Penicillium funiculosum: production, properties and application to cellulose hydrolysis. Journal of industrial microbiology \& biotechnology. 2010; 37 151-158.

143. Ellilä S, Fonseca L, Uchima C, et al. Development of a low-cost cellulase production process using Trichoderma reesei for Brazilian biorefineries. Biotechnology for biofuels. 2017; 10: 30 .

144. Ang S, Shaza E, Adibah Y, et al. Production of cellulases and xylanase by Aspergillus fumigatus SK1 using untreated oil palm trunk through solid state fermentation. Process Biochemistry. 2013: 48: 1293-1302.

145. Shruthi K, Yadav PS, Prasad BS, et al. Cellulase production by Aspergillus unguis in solid state fermentation. Journal of Forestry Research. 2019; 30 205-212.

146. Imran M, Anwar Z, Irshad M, et al. Optimization of cellulase production from a novel strain of Aspergillus tubingensis IMMIS2 through response surface methodology. Biocatalysis and Agricultural Biotechnology. 2017; 12: 191198.

147. Singh R, Kumar R, Bishnoi K, et al. Optimization of synergistic parameters for thermostable cellulase activity of Aspergillus heteromorphus using response surface methodology. Biochemical Engineering Journal. 2009; 48: 28-35.

148. Deswal D, Khasa YP, Kuhad RC. Optimization of cellulase production by a brown rot fungus Fomitopsis sp. RCK2010 under solid state fermentation. Bioresource technology. 2011; 102: 6065-6072.

149. Manzoor N, Cao L, Deng D, et al. Cellulase extraction from cellulolytic bacteria promoting bioelectricity production by degrading cellulose. Journal of Electroanalytical Chemistry. 2018; 829: 241-248.

150. Yotchaisarn $M$, Saengha $W$, Karirat $T$, et al. Identification of CellulaseProducing Bacteria from Soil in Nasinuan Forest, Kantarawichai District, Mahasarakham Province. 2020.

151.Singh S, Sivakumar N, VERMA JP. Developing thermophilic efficien cellulose degrading consortium for glucose production from different agroresidues. Frontiers in Energy Research. 2019; 7: 61.

152. Hebbale D, Bhargavi R, Ramachandra T. Saccharification of macroalgal polysaccharides through prioritized cellulase producing bacteria. Heliyon. 2019; 5: e01372.
153. Ariffin $\mathrm{H}$, Abdullah N, Umi Kalsom M, et al. Production and characterization of cellulase by Bacillus pumilus EB3. Int J Eng Technol. 2006; 3: 47-53.

154. Reddy KV, Vijayalashmi T, Ranjit P, et al. Characterization of some efficient cellulase producing bacteria isolated from pulp and paper mill effluent contaminated soil. Brazilian Archives of Biology and Technology. 2017; 60.

155. Aslam S, Hussain A, Qazi JI. Production of cellulase by Bacillus amyloliquefaciens-ASK11 under high chromium stress. Waste and Biomass Valorization. 2019; 10: 53-61

156. Ekperigin M. Preliminary studies of cellulase production by Acinetobacte anitratus and Branhamella sp. African Journal of Biotechnology. 2007; 6.

157. Liu H, Zeng L, Jin Y, et al. Effect of Different Carbon Sources on Cellulase Production by Marine Strain Microbulbifer hydrolyticus IRE-31-192. Applied biochemistry and biotechnology. 2019; 188: 741-749.

158. Xu F, Wang J, Chen S, et al. Strain improvement for enhanced production of cellulase in Trichoderma viride. Applied Biochemistry and Microbiology. 2011: 47: 53-58

159. Adsul M, Bastawde K, Varma A, et al. Strain improvement of Penicillium janthinellum NCIM 1171 for increased cellulase production. Bioresource technology. 2007; 98: 1467-1473.

160. Vu VH, Pham TA, Kim K. Improvement of fungal cellulase production by mutation and optimization of solid state fermentation. Mycobiology. 2011; 39: $20-25$.

161. Gao J, Qian Y, Wang Y, et al. Production of the versatile cellulase for cellulose bioconversion and cellulase inducer synthesis by genetic improvement of Trichoderma reesei. Biotechnology for biofuels. 2017; 10: 1-16.

162. Isaac GS, Abu-Tahon MA. Enhanced alkaline cellulases production by the thermohalophilic Aspergillus terreus AUMC 10138 mutated by physical and chemical mutagens using corn stover as substrate. Brazilian Journal of Microbiology. 2015: 46: 1269-1277.

163. Qian Y, Zhong L, Sun Y, et al. Enhancement of cellulase production in Trichoderma reesei via disruption of multiple protease genes identified by comparative secretomics. Frontiers in microbiology. 2019: 10: 2784

164. Liu G, Zhang L, Qin Y, et al. Long-term strain improvements accumulate mutations in regulatory elements responsible for hyper-production of cellulolytic enzymes. Scientific reports. 2013; 3: 1-7.

165. Chandra M, Kalra A, Sangwan NS, et al. Development of a mutant of Trichoderma citrinoviride for enhanced production of cellulases. Bioresource technology. 2009; 100: 1659-1662.

166. Zhong $\mathrm{Y}$, Wang $\mathrm{X}, \mathrm{Yu} \mathrm{H}$, et al. Application of T-DNA insertional mutagenesis for improving cellulase production in the filamentous fungus Trichoderma reesei. Bioresource technology. 2012: 110: 572-577.

167. Sangkharak K, Vangsirikul P, Janthachat S. Strain improvement and optimization for enhanced production of cellulase in Cellulomonas sp. TSU03. African Journal of Microbiology Research. 2012; 6: 1079-1084.

168. Rignall TR, Baker JO, McCarter SL, et al. Effect of single active-site cleft mutation on product specificity in a thermostable bacterial cellulase. Applied biochemistry and biotechnology. 2002: 98: 383-394.

169. Baker JO, McCarley JR, Lovett R, et al. Catalytically enhanced endocellulase Cel5A from Acidothermus cellulolyticus. Applied biochemistry and biotechnology. 2005; 121: 129-148.

170. Adepu K. UV mutagenesis treatment for improved production of endoglucanase and $\beta$-glucosidase from newly isolated thermotolerant actinomycetes, Streptomyces griseoaurantiacus. Bioresources and Bioprocessing. 2015; 2: 1-10.

171. Bhatia R, Kumar R, Rathour R, et al. Enhancement of cellulose degradation potential of Bacillus sp. Hcb-21 through Mutagenesis. Journal of Microbial and Biochemical Technology. 2017; 9: 257-265.

172. Abdullah R, Zafar W, Nadeem M, et al. Random mutagenesis and media optimisation for hyperproduction of cellulase from Bacillus species using proximally analysed Saccharum spontaneum in submerged fermentation. Natural product research. 2015; 29: 336-344. 
173. Fang $\mathrm{X}$, Yano $\mathrm{S}$, Inoue $\mathrm{H}$, et al. Strain improvement of Acremonium cellulolyticus for cellulase production by mutation. Journal of Bioscience and Bioengineering. 2009; 107: 256-261.

174. Karthikeyan P. Optimization of cellulase enzyme production from Pleurotus ostreatus and Calocybe indica. Int J Pharm Biol Sci. 2015; 5: 11-16.

175. Mrudula S, Murugammal R. Production of cellulase by Aspergillus niger under submerged and solid state fermentation using coir waste as a substrate. Brazilian Journal of Microbiology. 2011; 42: 1119-1127.

176. Yadav P, Chauhan P, Gahlout M, et al. Isolation, screening and optimization of process parameters for enhanced production of cellulase by solid state fermentation. International Journal of Advanced Research in Biological Sciences. 2016; 3: 21-27.

177. Kulkarni N, Vaidya T, Rathi G. Optimization of cellulase production by Aspergillus species under solid state fermentation. Pharma Inn J. 2018; 7 : 193-196.

178. Dutt D, Kumar A. Optimization of cellulase production under solid state fermentation by Aspergillus flavus (AT-2) and Aspergillus niger (AT-3) and its impact on stickies and ink particle size of sorted office paper. Cell Chem Technol. 2014; 48: 285-298.

179. Premalatha N, Gopal NO, Jose PA, et al. Optimization of cellulase production by Enhydrobacter sp. ACCA2 and its application in biomass saccharification. Frontiers in microbiology. 2015; 6: 1046.
180. Irfan M, Mushtaq Q, Tabssum F, et al. Carboxymethyl cellulase production optimization from newly isolated thermophilic Bacillus subtilis K-18 for saccharification using response surface methodology. AMB Express. 2017; 7: 29.

181. Chellapandi $P$, Jani HM. Production of endoglucanase by the native strains of Streptomyces isolates in submerged fermentation. Brazilian Journal of Microbiology. 2008; 39: 122-127.

182. Mmango-Kaseke Z, Okaiyeto K, Nwodo UU, et al. Optimization of cellulase and xylanase production by Micrococcus species under submerged fermentation. Sustainability. 2016; 8: 1168.

183. Dourado F, Bastos M, Mota M, et al. Studies on the properties of Celluclast/ Eudragit L-100 conjugate. J Biotechnol. 2002; 99: 121-131.

184. Humpf HU, Schreier P. Bound aroma compounds from the fruit and the leaves of blackberry (Rubus laciniata L.). J Agr Food Chem. 1991; 39: 1830 1832.

185. Rai P, Majumdar G, Gupta SD, et al. Effect of various pretreatment methods on permeate flux and quality during ultrafiltration of mosambi juice. J Food Eng. 2007; 78: 561-568. 